\title{
Review of Ethiopia's Global Position in Honey and Other Bee Products Production and Marketing: Analysis of Sectoral Opportunities and Limitations
}

\author{
Tekeba Nega* and Yeshitela Eshete \\ Ethiopia Meat and Dairy Industry Development Institute, Ethiopia
}

Received: 帅: October 11, 2018; Published: 眥: October 29, 2018

*Corresponding author: Tekeba Nega, Ethiopia Meat and Dairy Industry Development Institute, Ethiopia

\begin{abstract}
Among many macro-economic development pillars of Ethiopia, raising agricultural output and productivity, promoting industrialization, huge investment in infrastructure and export promotion and diversification are the major focus of Ethiopian government. Honey and wax being exportable food items have been contributing to the foreign export earnings of the nation since the beginning of honey processing. However, the share of honey and beeswax exported from the annual production is less than $2 \%$. On the other hand, there are a number of other bee products that can be used in the lucrative market that exists in most parts of the world. In addition to honey and bee wax, propolis, royal jelly, pollen and bees' venom, have got a very huge demand for their several health and nutritional benefits and economic importance. Therefore, this study is initiated first to review the opportunities and challenges of honey production and trade in Ethiopia and seeking strategic intervention options to unleash the potential. Data from national and international sources were used to meet the objectives of this review study. Based on the results, honey and other bee products, in addition to their economic importance, can contribute to microbial inhibition, wound healing, gastrointestinal disorders, allergies, gynecological, oral and dermatological problems and also help for cancer victims and others.

However, due to knowledge gap, failure in meeting international requirements including food safety standards like ISO and HACCP, limited promotion done in marketing and poor linkage among stakeholders, limited access to packaging materials, small scale production (losing out on economies of scale), quality challenges including adulteration and fraud, the country is not benefiting from the huge resources. The revival in the private sector participation in the industry has not been accompanied either by a significant increase in volume nor in the diversification of export. Therefore, technical backups in the production and processing of other niche bee products are very important; policy support in terms of diverse incentive mechanisms; encouraging more research and development work so as to benefit smallholder farmers and processors and the need for traceability and residue monitoring exercise, new products lines including flavored honey has to be in place to be competent in the global market. Better business communication with potential buyers and back and forth linkage with stakeholders along the value chain are also very important for the transformation of the sector from the current staggering stage to globally competitive agribusiness.
\end{abstract}

Keywords: Other Bee Products; Pollen; Propolis; Royal Jelly; Transformation; Venom

\section{Introduction}

Beekeeping is a very long standing and deep rooted household activity in Ethiopia. Ethiopia has a huge potential for beekeeping production because of its endowment with diversity in climate and vegetation resources for beekeeping [1]. According to [2], the contribution of Ethiopia to Africa and world honey production is $23.58 \%$ and $2.13 \%$, respectively. In Ethiopia, there are about 10 million bee colonies of which 5 million are hived and over 800 identified honey bee forages $[3,4]$. According to different sources, the annual honey production potential of the country is estimated to be 500,000 tones of honey and 50,000 tones of bees wax. According to $[5,6]$ report, the annual total production of honey reached 53,000 tones which is not more than $10 \%$ of the potential [7]. According to the same source, there is an annual beeswax production of 3,800 tones in Ethiopia. Out of the total honey produced, roughly $80 \%$ is utilized for local brewing called Tej (honey wine) with the balance being sold either as table honey in the domestic market or to the export market $[8,9,10]$. This amount of honey produced when it is translated into percapita honey consumption using the current $100,000,000$ population, is not more than $0.53 \mathrm{~kg} / \mathrm{head}$ which is very small as compared to the potential.

According to [11], the per capita honey consumption in Ethiopia between 1997 to 2005 varies between 0.23 and 0.42 which implies there is no significant growth parallel to population growth. Similarly, the major honey exporting countries like China 
and Argentina also have a very small annual consumption rates of 0.1 to $0.2 \mathrm{~kg}$ per capita [12], respectively. As the number of national statistics including Central Statistical Agency of Ethiopia indicated, the export share of both honey and bee wax from the total produced is not more than $2 \%$ in Ethiopia. So far the country is also limited only on honey and bee wax production and processing no other bee products used in the country. Therefore, this review study is initiated to explore the current potentials, challenges and the way foreword to leverage the subsector and benefit the society.

\section{Ethiopia's Global Position in Honey and Beewax Produc- tion}

According to [13], on the average the total honey production per year in the world is estimated to be 1.3 million tones. Of the total production developing countries all to gather produce about $47 \%$ of the world total honey production. The major producers are China, Turkey, Argentina, Ukraine, Russian Federation etc [14]. Between 2001 and 2013, the total cumulative honey produced for some selected countries indicated that, China is the leading honey producing country followed by EU as indicated in (Figure 1). In Ethiopia beekeeping is an important agricultural activity due to its varied ecological and climatic conditions [15]. According to [16], about 5.21 million hived colonies is estimated to be found in rural sedentary areas of the country. This makes Ethiopia the country with the largest number of bee colonies in Africa. The huge resources in the country coupled with ancient culture of the people of the country ranked Ethiopia one of the largest honey producers which makes first in Africa and tenth in the world and the third largest beeswax producer worldwide [13,15,17].

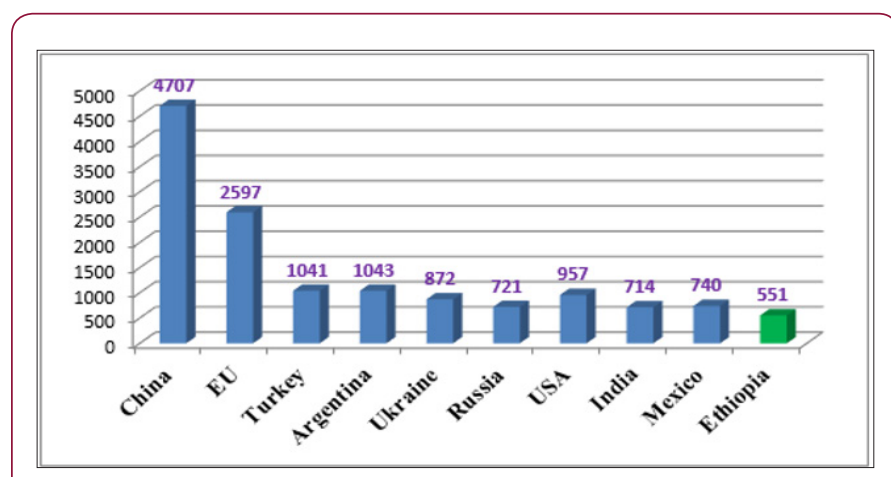

Figure 1: World honey production between 2001-2013 (1000 T).

Ethiopia honey production accounts for approximately $2.5 \%$ of world production and $21.7 \%$ of African honey production [18]. The majority which is above $80 \%$ of the honey produced is used for honey wine making and the rest 30 and less is used for local consumption and for little export [8-10]. The major destination market for Ethiopian honey and beeswax include Germany, Norway, Sudan, USA, UK, Japan etc (personal observation from Ethiopia custom authority report). Productivity from traditional hives is very low, with an average of 5-6 kg per year, while production from improved hives (including transitional hives) reaches levels of 18$30 \mathrm{~kg}$ per year [19].

\section{Ethiopia Honey and Beeswax Marketing Performance}

Ethiopia main market for honey is traditional honey wine making, called tej. Since this local brew doesn't require high quality honey, crude honey is the major type of honey produced in Ethiopia. The issue of quality has therefore never become a priority among Ethiopian producers and that has become one of the problems for the sector [20]. The total volume of honey production in Ethiopia in 2007-2011 was 163,257.42 tons, of which 99.2 percent was consumed domestically and 0.8 percent was exported [21]. According to the same source, the total volume of Ethiopian honey exports in 2007-11 was 1,297.72 ton, with the total value of US\$4,066,528 of which Sudan was the single biggest importer of Ethiopian honey in terms of volume and monetary value during this time. Although the volume of honey export increased slightly during the same period, the share of the export as compared to honey produced was very low. Another reports indicated that, the export performance of Ethiopian honey increased significantly from 151.2 tons in 2006 to 728.6 tons in 2011 meaning 382\% increment but still very weak as compared to it's international peers and potentials [22-24].

The market for honey in Ethiopia is generally not well developed, mainly due to a limited number of buyers relative to the number of producers (suppliers), poor market infrastructure and information [10]. On top of this limitation, UNCOMTRADE ITC statistics indicated that between 2012-2016, Ethiopia imported natural honey from different countries with the total value of $\$$ 149,000 in which some amounts may be re-imported. Honey and other apiculture products (i.e. beeswax, propolis, pollen, royal jelly and bee venom) are among the growing export commodities with good potential for a number of African countries. The global honey market offers huge opportunities for Ethiopian honey. Even though, we are not fully ready to absorb EU markets, the potential market in EU indicated that in 2009 alone the member countries produced only $60 \%$ of their demand and the remaining $40 \%$ was imported [19]. Ethiopia exported its first consignment of honey to the European Union in 2008 after three years period of preparations towards attaining Third country listing status [19].

The volume and value of honey exported from about 40 registered companies in Ethiopia was in an increasing trend till 2013 but then after it started declining as observed in (Figure 2), and [9]. There are a number of reasons for this but the stringent requirements from the buyers side year after year following honey quality deterioration mainly due to adulteration and fraud are the major ones [25]. The other challenges in the country which include but not limited are illegal cross boarder honey trade; the recurrent draught which affect the supply line, the increase in the price of honey in the local market, the increase in the cost of laboratory service which usually demand foreign currency are some of the factors that affect the export market for Ethiopia honey. Despite having the highest bee density and being the leading country in honey production and largest beeswax exporting countries in Africa, the share of the subsector to GDP has never matched with the 
huge numbers of honey bee colonies and other resources [26]. Even though Ethiopia has a 10th position in the world and first in Africa in honey production, it's export performance as compared to some selected countries is very poor as indicated in (Figure 3). The graph clearly indicated that in most of the cases the export performance of almost all countries declined in 2016 as the requirement getting tough and the fraud is getting worse globally.

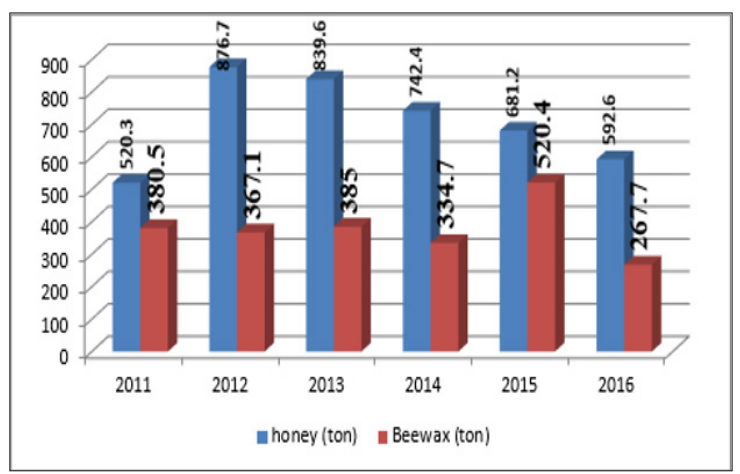

Figure 2: Trends of honey and bee wax export performance of Ethiopia.

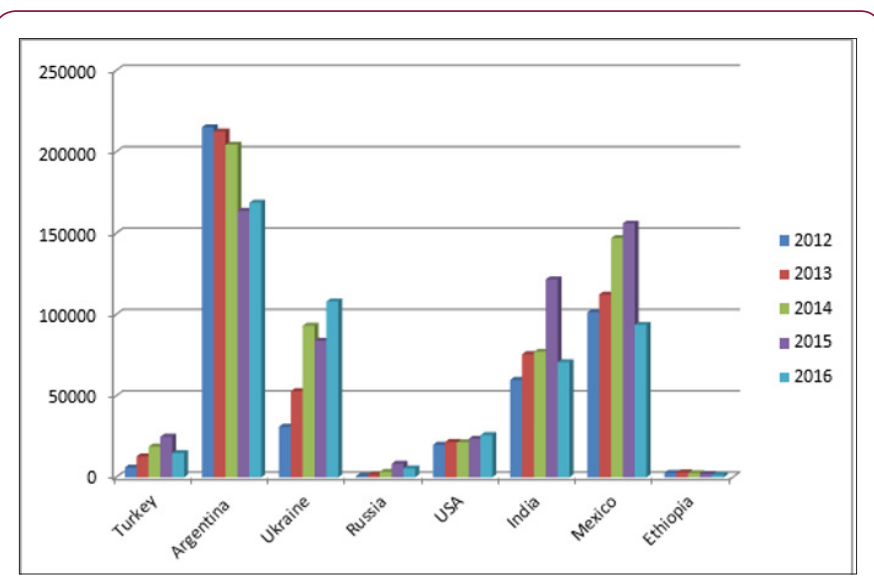

Figure 3: List of selected honey exporting countries performance (US Dollar in thousands).

\section{Major Biological Activities of Honey and Other Bee Products}

Apitherapy is the use of bee products such as honey, pollen, propolis, royal jelly, bee venom and wax to treat ailments such as liver, cardiovascular and gastrointestinal problems and wound healing [27]. Ancient Egyptians, Assyrians, Chinese, Greeks and Romans employed honeybee products for wounds and diseases of the intestine [28]. These honey products are highly rich in active components such as flavonoids, phenolic acid, phenolic compounds, terpenes and enzymes, which has a biological function in preventing some diseases and promoting good health [29]. Honey, propolis, and royal jelly have distinct efficacies with significant nutritional properties and functional values. But some precautions need to be taken in case of allergens associated with bee products and in finding the right intake dosage [29-39]. The major biological activities of different bee products are summarized and presented in (Table 1) [40-41].
Table 1.

\begin{tabular}{|c|c|c|}
\hline Bee product type & Biological activities & Reference \\
\hline \multirow{6}{*}{ Honey } & Body pain and muscle fatigue & [30] \\
\hline & \multirow{2}{*}{$\begin{array}{c}\text { General strength; mental efficiency; } \\
\text { use as antiseptics, hider growth of } \\
\text { microbes }\end{array}$} & [31] \\
\hline & & [32] \\
\hline & $\begin{array}{l}\text { Digestion and assimilation; } \\
\text { metabolic and cardiovascular } \\
\text { health }\end{array}$ & $\begin{array}{l}{[34]} \\
{[35]} \\
{[36]}\end{array}$ \\
\hline & $\begin{array}{l}\text { Cold and flu; mouth \& throat } \\
\text { infection }\end{array}$ & [29] \\
\hline & Constipation and diarrhea & [37] \\
\hline Propolis & $\begin{array}{l}\text { Used to treat diabetes, anticancer, } \\
\text { dental action, anti-inflammatory; } \\
\text { dermatological problems; } \\
\text { gastrointestinal disorders; allergies }\end{array}$ & $\begin{array}{l}{[31]} \\
{[38]} \\
{[29]}\end{array}$ \\
\hline Royal Jelly & $\begin{array}{l}\text { Reproductive health, } \\
\text { neurodegenerative disorders, } \\
\text { wound healing, aging }\end{array}$ & [29] \\
\hline Bee venom & $\begin{array}{l}\text { To treat arthritis \& other } \\
\text { inflammatory conditions }\end{array}$ & [49] \\
\hline \multirow{2}{*}{ Bee pollen } & \multirow{2}{*}{ Antioxidant property, } & [31] \\
\hline & & {$[40]$} \\
\hline
\end{tabular}

\section{Major Opportunities of Bee Keeping in Ethiopia}

a) The opportunity to produce organic products in the country to penetrate the global market

b) Political commitment from the government side and (fast economic growth)

c) The existence of a number of development partners which support the sub-sector

d) Investment incentives in terms of different tax exemptions

e) A number of waters shed management activities for integration with apiculture

f) Expansion and the coming into being of Integrated AgroIndustry park

g) The potential to produce mono-floral honey through integration with commercial plantation sites like coffee

h) The expansion of area closure (free from animal and human)

i) Untouched potential for other bees' products (propolis, royal jelly, pollen, venom)

j) The consensus reached for intra-African trade agreement (44 countries)

k) Growing and unsatisfied domestic and promising international markets

l) The presence of naturally conserved biosphere forest in the country

m) Major challenges of the apiculture sector in Ethiopia: 
n) Lack of mandatory standards resulting in adulteration and other fraud

o) Limited products for the market

p) Poor Market infrastructure and linkage

q) Limited technical knowhow coupled with lack of inputs and technology

r) Absence of branding

s) Absence of internationally accredited laboratory facilities for residue monitoring

t) Illegal export of honey across the boarders

u) Too general extension service

v) Traditionalism in the sector

w) Limited research and development capacity to promote honey products diversification

\section{x) Packing related problems}

y) Limited regulatory functions including testing and certifying laboratories

z) Weak organizations representing the interests of beekeepers. Poor linkage between producers and buyer

\section{Conclusion and Recommendations}

The demand for honey and other bee products as food and medicine for mankind has been in existence since time immemorial. On the other hand, even though high value is attached to other bee products like propolis, venom, royal jelly and pollen, their use by developing countries is very limited even not in existence in the case of Ethiopia. Ethiopia unlike most of her peers is potentially blessed with honey and beeswax. But the benefit from the subsector in terms of domestic supply and export market is very poor and totally limited to honey and beeswax. This is mainly attributed to lack of mandatory standards resulting in adulteration and other fraud; limited products for the market; poor market infrastructure and linkage; limited technical knowhow coupled with lack of inputs and technology; absence of laboratory facilities for residue monitoring; illegal export of honey across the boarders; too general extension service etc.

Therefore, from this review study it is recommended that appropriate infrastructure should be in place for marketing and quality control, strong network between producers and buyers should be established, dependable by-laws and enforcing mechanism from the government side should be in place along the honey value chain, capacity building of both producers and processors, commercialization of the sector to be competitive in the global market and standardization of the products and food safety requirements should be properly addressed. Further research and development intervention how to use the other bee products so as to leverage the export market should be given a higher priority.

\section{References}

1. Kidane MY (2014) Assessment of Beekeeping practices and honey production in Mejhengir Zone of Godere District, Gambella people National Regional State, Ethiopia. MSc Thesis Haramaya University.

2. Workneh, Abebe, Ranjitha P (2011) Beekeeping Subsector Challenges and Constraints in Atsbi Wemberta District of Eastern Zone, Tigray Region, Ethiopia. Journal of Agricultural Extension and Rural Development 3(1): 8-12.

3. Kebede Nigussie, PA Subramanian, Gebrekidan Mebrahtu (2011) Physicochemical Analysis of Tigray Honey: An Attempt to Determine Major Quality Markers of Honey. Chemical Society of Ethiopia Addis Ababa.

4. Gemechis Legesse Yadeta (2015) Honey production and marketing in Ethiopia. American Journal of Life Sciences 3(1): 42-46.

5. CSA (Central Statistical Agency) (2011) Agricultural Sample Survey Report for 2011 Ethiopia.

6. USAID (United States Agency for International Development) (2012) Agricultural Growth Program-Agribusiness and Market Development (AGP-AMDe) Project.

7. Submitted by ACDI/VOCA to Contracting Officer's Representative Tewodros Yeshiwork, USAID Ethiopia.

8. CSA (Central Statistical Agency) (2012) Agricultural Sample Survey Report for 2012, Ethiopia.

9. Tadesse B, Phillips D (2007) Ensuring Small Scale Producers in Ethiopia to Achieve Sustainable and Fair Access to Honey Markets. International Development Enterprises (IDE)and Ethiopian Society for Appropriate Technology (ESAT).

10. Amanuel T (2011) Value chain and cost benefit analysis of honey production and its implication on household food security: a comparative analysis of certified and conventional honey in Ginbo Wereda, Southern Ethiopia. Addis Ababa University college of development studies, Food security studies program.

11. Dayanandan (2015) Opportunities and Challenges of Apiculture in Ethiopia. Hawassa University, Ethiopia.

12. Ayalew Kassaye (2008) Establishment of Apiculture data base in Ethiopia. Honey and beeswax value chain of BOAM programme, SNV Netherlands Development Organization, Addis Ababa, Ethiopia.

13. Stefan Bogdanov, Tomislav Jurendic, Robert Sieber, Peter Gallmann (2008) Honey for Nutrition and Health: a review. American Journal of the College of Nutrition 27: 677-689.

14. Teklu Gebretsadik, Dinku Negash (2016) Honeybee Production System, Challenges And Opportunities In Selected Districts Of Gedeo Zone, Southern Nation, Nationalities And Peoples Regional State, Ethiopia. International Journal of Research-Granthaalayah 4(4): 49-63.

15. FAOSTAT (2014) Food and Agriculture Organization Statistics.

16. Haftu K, Gezu T (2014) Survey on the honey production system, challenges and opportunities in selected areas of Hadya zone, Ethiopia. Journal of Biotechnology and Sustainable Development. Academic Journal 6(6): 60-66.

17. CSA (Central Statistical Agency) (2012) Agricultural sample Survey 2012/13. Report on livestock and livestock characteristics. Addis Ababa Statistical Bulletin p. 570.

18. Sisay Fikru (2015) Review of honey bee and honey production in Ethiopia. J Anim Sci Adv 5(10): 1413-1421.

19. MoARD (Ministry of Agriculture and Rural Development) (2007) Livestock development master plan study phase I report-data collection and analysis. Addis Ababa Ethiopia. 
20. Paulos Desalegne (2011) Ethiopian honey: Accessing International markets with inclusive business and sector development. Post Implementation review report.

21. Sarah Drost (2011) Multi-stakeholder platform contribution to value chain development. The honey and beeswax value chain in Ethiopia Partnerships Resource Centre /SDC_maastricht School of mangement Project.

22. Mikhail M, Glenn P, Jenkins, Richard, R Barichello, et al. (2013-17). Honey production in Ethiopia: A cost-benefit analysis of modern versus traditional beekeeping technologies. Development discussion paper.

23. EEPA (Ethiopian Export Promotion Agency) (2010) Ethiopian export data. Ethiopian Export Promotion Agency. Addis Ababa, Ethiopia.

24. Assefa M (2011) Pro-poor value chains to make market more inclusive for the rural poor: Lessons from the Ethiopian honey value chain. Danish Institute for International Studies, Copenhagen, Denmark, pp. 35-50.

25. EEPA (Ethiopian Export Promotion Agency) (2012) Ethiopian export data. Ethiopian Export Promotion Agency. Addis Ababa, Ethiopia.

26. Norberto L, Garcia (2014) A study of the causes of falling honey prices in the international market. Departmento de Agronomia. Universidad Nacional Del Sur Bahia Blanca Argentina.

27. Mulubrihan Bayissa Tullu (2014) Assessment of honey quality gap: The case of smallholder holeder farmers of sheka zon, Anderacha district, Southern Ethiopia. Hogschoool VHL University of Applied Sciences.

28. Ezz El-Arab, AM, SM Girgis, ME Hegazy, Abd AB El-Khalek, et al. (2006) Effect of dietary honey on intestinal micro-flora and toxicity of mycotoxins in mice. BMC Complement Altern 6: 1-13.

29. Al-Jabri AA (2005) Honey, milk and antibiotics. Afr J Biotechnol 4: 15801587.

30. Visweswara Rao Pasupuleti, Lakhsmi Sammugam, Nagesvari Ramesh, Siew Hua Gan (2017) Honey, Propolis, and Royal Jelly: A Comprehensive Review of Their Biological Actions and Health Benefits. Hindawi Oxidative Medicine and Cellular Longevity.

ISSN: 2574-1241

DOI: 10.26717/BJSTR.2018.10.001969

Tekeba Nega. Biomed J Sci \& Tech Res

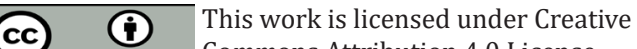

This work is licensed under Creative

Submission Link: https://biomedres.us/submit-manuscript.php
31. Global Forum on Food Security and Nutrition (2015) Food and Agricultural Organization of the United nations.

32. Bakalo Basa, Wendimagegnehu Belay, Alebachew Tilahun, Ayichew Teshale (2016) Review on Medicinal Value of Honeybee Products: Apitherapy. Wolaita Sodo University, School of Veterinary Medicine, Ethiopia. Advances in Biological Research 10 (4): 236-247.

33. Ahmad A, MK Azim, MA Mesaik, RA Khan (2008) Natural honey modulates physiological glycem. In response compared to simulated honey and D-glucose. J Food Sci 73: 165-167.

34. Olaitan PB, EO Adeleke, OI Ola (2007) Honey: a reservoir for microorganisms and an, inhibitory agent for microbes. Afr Health Sci 7: 159-160.

35. Kandil A, M El-Banby, GK Abdel-Wahed, M Abdel-Gawwad, M Fayez, et al. (2003) Curative properties of true floral and false non-floral honeys on induced gastric ulcers. J Drug Res 17: 103-106.

36. R Afroz, E Tanvir, N Karim (2016) Sundarban honey confers protection against isoproterenol-induced myocardial infarction in Wistar rats. BioMed Research International.

37. Christy E, Manyi-Loh, Anna M, Clarke, Roland N, et al. (2011) An overview of honey:Therapeutic Properties and contribution in Nutrition and Human Health. African Journal of Microbiology Research 5(8): 844852.

38. LJ Brandt, CM Prather, EM Quigley, LR Schiller, P Schoenfeld, et al. (2005) Systematic review on the management of chronic constipation in North America. The American Journal of Gastroenterology 100(1): 5-21.

39. Segeren P, V Mueder, J Beetsma, R Sommeijer (2011) Beekeeping in the tropics 3 (Ed) CTA, Wageningen Netherlands 12: 4-14

40. Alvarez-Suarez JM, S Tulipani, S Romandini (2010) Contribution of honey in nutrition and human health: a review. Mediterr J Nutr Metab 3:15-23.

41. Kocot J, Kiełczykowska M, Luchowska-Kocot D, Kurzepa J, Musik I, et al. (2018). Antioxidant Potential of Propolis, Bee Pollen, and Royal Jelly: Possible Medical Application. Oxid Med Cell Longev 2: 7074209.

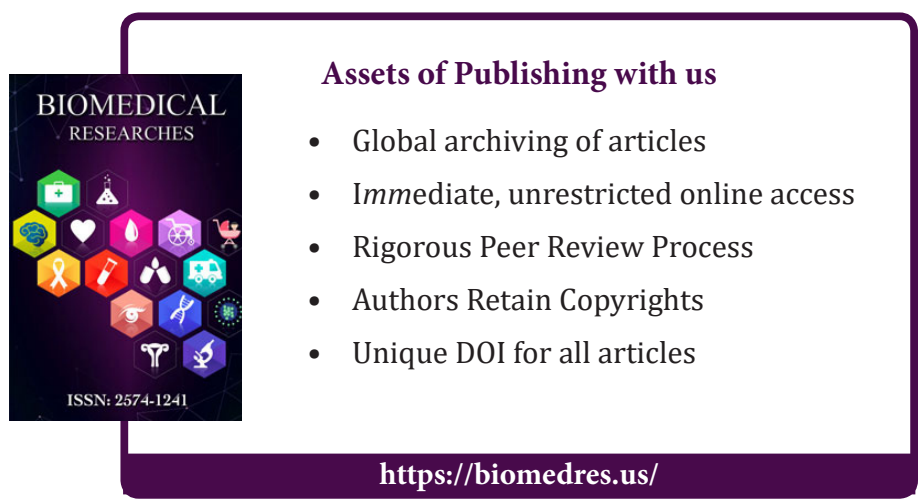

